\title{
RESPONSE OF DATE PALM (Phoenix dactylifera L.) OFF SHOOTS TO BIOSTIMULANT EM AND CHEMICAL FERTILIZER UNDER NURSERY CONDITION
}

(Received: 14.9.2015)

\author{
By \\ L. M. Abdel-Galeil \\ Central Laboratory of Date palm Research and Development, \\ Agricultural Research Center,Giza, Egypt
}

\begin{abstract}
A trial was carried out at the Experimental Farm of the Hort. Res. Inst., A.R.C., Giza, Egypt during 2014 and 2015 seasons to study the effect of individual application of Em biostimulant solution at 25 $\mathrm{ml} / \mathrm{l}$, NPK complete chemical fertilizer (20:20:20+ microelements) at the rates of $0,2.5,5.0,7.5$ and $10.0 \mathrm{~g} / \mathrm{bag}$ and their combinations on growth and chemical composition of 2 year - old off shoots of date palm (Phoenix dactylifera L.) cv. Siwi planted in 50-cm-diameter plastic bags filled with about $35 \mathrm{~kg}$ of a mixture of sand and clay $(2: 1, \mathrm{v} / \mathrm{v})$ under the full sun.

The results showed that all fertilization treatments used markedly improved all vegetative growth characteristics with various significant levels when compared to the control in both seasons. The results indicated also that EM solution alone gave means closely near those gained by NPK complete fertilizer at $5 \mathrm{~g} / \mathrm{bag}$ with few exceptions in the two seasons. Moreover, increasing the application rate of NPK fertilizer to $7.5 \mathrm{~g} / \mathrm{bag}$ or more did not cause a pronounced increment in growth, but combining between EM treatment and NPK fertilizer at any rate did so, with the superiority of combining between $25 \mathrm{ml} / \mathrm{l} \mathrm{EM}$ and $5 \mathrm{~g} \mathrm{NPK} / \mathrm{bag}$, as this combination gave the highest means over other combined treatments in both seasons. Similar observations were also attained concerning the leaflet content of $\mathrm{N}, \mathrm{P}, \mathrm{K}$, total indoles, chlorophylls a and $\mathrm{b}$ and carytenoids.

Hence, it can be recommended to treat the 2year old offshoots of date palm cv. Siwi cultivated in $50 \mathrm{~cm}$ diameter plastic bags with EM solution at $25 \mathrm{ml} / 1$ and NPK complete fertilizer at $5 \mathrm{~g} / \mathrm{bag}$ to improve growth and quality of such offshoots before transferring to the permanent field.
\end{abstract}

Key words: Date Palm-Phoenix dactylifera L., EM biostimulant, NPK fertilization.

\section{INTRODUCTION}

Phoenix dactylifera L., date palm (Fam. Palmaceae) is one of the common and popular fruit grown in tropical and subtropical areas. There are many cultivars of date plam, some of them give semi-dry fruits, among which cv. Siwi. It is one of the most famous and distributed cultivars in Egypt, especially at the governorates of New Valley, Wahat, Giza and Fayoum. Each cv. Siwi date palm tree yields about 90 up to more than $150 \mathrm{~kg}$ fruits per year. The fruits are somewhat big-sized, reaching 3.5$4.0 \mathrm{~cm}$ in length and $2.0-2.5 \mathrm{~cm}$ in diameter. They are yellow at mature stage as they can be consumable at this phase. After drying, these fruits turn to deep brown. It is among the highly qualified cultivars for processing and packing as pressed dates. The fruits can be stored for long time after harvest.

It is well known that all palm plants grow slowly, and fertilizing them with either chemical or bio-preparations usually enhance growth, especially at the early stages. In this concern, Abdel-Galeil et al. (2010) found that the survival and rooting percentages, root length and No. roots/ offshoot of date palm cv. Zaghloul were linearly increased with increasing the level of commercial liquid fertilizer (10N: 10P: $10 \mathrm{~K}+$ micro-elements) from 5 to $10 \mathrm{ml} / \mathrm{l}$. A similar trend was also attained regarding leaf length, No. new formed leaves/ offshoot, fresh and dry weights of the new formed leaves, as well as the percentages of $\mathrm{N}, \mathrm{P}$ and $\mathrm{K}$ in the new leaves. Likewise, the growth parameters were linearly increased with increasing the level of commercial liquid fertilizer $(10 \mathrm{~N}: 10 \mathrm{P}: 10 \mathrm{~K}+$ microelements) from 5 to $10 \mathrm{ml} / \mathrm{l}$. A similar trend was also attained regarding leaf length, No. new formed leaves / offshoots, fresh and dry weights of the new formed leaves, as well as the 
percentages of $\mathrm{N}, \mathrm{P}$ and $\mathrm{K}$ in the new leaves. However, Abdel-Galeil (2010a) on date palm cv. Malacabe mentioned that combining NPK liquid fertilizer (10:10:10+ microelements) at $2 \mathrm{ml} / \mathrm{l}$ as a foliar spray and at $20 \mathrm{ml} / \mathrm{l}$ as a soil drench greatly improved trunk length, No. leaves/plantlet and leaf width. Connecting between potassien-N (K-N) at $2 \mathrm{ml} / \mathrm{l}$ as a foliar spray and NPK liquid fertilizer (10 : $10: 10+$ microelements) at $20 \mathrm{ml} / \mathrm{l}$ as a soil drench significantly increased trunk length, No. leaves/ plant, leaf width, as well as content of chlorophyll $\mathrm{a}$ and $\mathrm{b}$, carotenoids, $\mathrm{N}, \mathrm{P}$ and $\mathrm{K}$ in the leaves of cv. Sakkoty plant (Abdel-Galeil, 2010a).

On ornamental plants, Agina et al. (2005) on Ficus macrocarpa cv. Hawaii, reported that foliar application of kristalon (19 : 19: 19+ micronutrients) markedly improved vegetative growtn, fresh and dry weights of leaves, stem and roots, as well as pigments and minerals content in the leaves. Similarly, the results were recorded by Kandeel et al. (2002) on Melia azedarach, Sarhan et al. (2002) on Taxodium disticum, Gad (2003) on Ficus benjamina, ElSayed et al. (2008) on Ficus macrocarpa cv. Hawaii, Abdel-Fattah et al. (2009) on Dracaena and Ruscus, Shahin et al. (2012) on Schefflera and Euonymus, El-Fouly et al. (2014) on Ficus deltoidea and Shahin et al. (2014) on Merremia dissecta.

A commercial Japanese product, EM is a biostimulant that contains more than 60 selected strains of "Effective Microorganisms", viz., Photosynthetic bacteria, lactic acid bacteria, yeast, actinomycetes and various fungi that improve growth and health of plants (Primavesi, 1999). Janas (2009) revealed that effective microorganisms (EM) is characterized by a wide spectrum of activity and complex effect on plant living environment. Thus, it may be used as foliar treatments, on the seeds or in soil application. Its effects on inducing plant disease resistance, yield creating and protective were observed in many industrial, medicinal and ornamental plant species. It also creates humus substance and regulates basic relations in the soils. Therefore, the EM bispreparation is used in many countries, on a large scale, in organic production of agricultural crops. In this regard, Thach et al. (1999) indicated that treatment orchids with EM led to larger stems, darker green leaves and accelerating flowering in Dendrobium plants. On jojoba, Sarhan et al. (2007) noticed that Biomagic (a commercial biopromotor) at $10 \mathrm{~g} / \mathrm{l}$ and inoculation with a mixture of Azotobacter and Bacillus significantly increased vegetative growth parameters, pigments content, total carbohydrates, $\mathrm{N}, \mathrm{P}, \mathrm{K}, \mathrm{Fe}, \mathrm{Zn}$ and $\mathrm{Cu}$ in the leaves. On the same line, were those results recorded by El-Seginy (2006) on pear and apricot and El-Sayed (2012) on paspalum turf.

This work was set out to discover the beneficial effects of both chemical fertilizer and biostimulant, alone or in combination on growth and quality of offshoots of date palm cv. Siwi.

\section{MATERIALS AND METHODS}

This study was conducted at the Experimental Farm of the Hort Res. Inst., ARC, Giza, Egypt during two consecutive seasons of 2014 and 2015 to reveal the effect of complete chemical fertilizer and EM biostimulant, solely or in combination treatments on growth and chemical composition of Siwi cultivar offshoots date palm.

Two-year-old uniform offshoots were selected carrying about 4-5 leaves. The bases of the selected offshoots were first dipped in a $0.5 \%$ solution of Topsin-M, 70\% WP (Sumitomo Chemical Co., Ltd., Osaka, Japan) for 30 minutes, and then planted on April, the $1^{\text {st }}$ for the two studied seasons in 50-cm-diameter plastic bags (one offshoot/bag) filled with about $35 \mathrm{~kg}$ of sand and clay soil mixture (2:1, by volume). Some physical and chemical properties of the sand and clay used in both seasons were determined according to the standard methods described by Richards (1954) and illustrated in Table (1).

After one week from planting, the planted offshoots were irrigated with 10 liters of fresh water/bag. On the $15^{\text {th }}$ of April, the offshoots received the following treatments:

Table (1): Some physical and chemical properties of the used sand and clay in both seasons.

\begin{tabular}{|c|c|c|c|c|c|c|c|c|c|c|c|c|c|c|}
\hline \multirow{2}{*}{ 总 } & \multicolumn{4}{|c|}{$\begin{array}{c}\text { Particle size distribution } \\
(\%)\end{array}$} & \multirow{2}{*}{ S.P } & \multirow{2}{*}{$\begin{array}{c}\text { E.C. } \\
\text { (ds/m) }\end{array}$} & \multirow{2}{*}{ pH } & \multicolumn{4}{|c|}{ Cations (meq/l) } & \multicolumn{3}{|c|}{ Anions (meq/l) } \\
\hline & $\begin{array}{c}\text { Coarse } \\
\text { sand }\end{array}$ & $\begin{array}{l}\text { Fine } \\
\text { sand }\end{array}$ & Silt & Clay & & & & $\mathrm{Ca}^{++}$ & $\mathbf{M g}^{++}$ & $\mathrm{Na}^{+}$ & $\mathbf{K}^{+}$ & $\mathrm{HCO}_{3}^{-}$ & $\mathrm{Cl}^{-}$ & $\mathrm{SO}_{4}^{-}$ \\
\hline Sand & 18.72 & 71.28 & 4.76 & 5.34 & 21.83 & 1.58 & 8.20 & 2.65 & 2.48 & 21.87 & 0.78 & 3.85 & 13.00 & 10.93 \\
\hline Clay & 7.46 & 16.75 & 34.53 & 40.89 & 41.76 & 2.18 & 8.33 & 16.93 & \begin{tabular}{|l}
9.33 \\
\end{tabular} & 20.44 & 0.37 & 3.82 & 1.46 & 41.79 \\
\hline
\end{tabular}


1. No fertilization, referred to as the control.

2. EM biostimulant solution consisting of 0.51 $\mathrm{EM}+11$ molasses +201 well water $(25 \mathrm{ml}$ $\mathrm{EM} / \mathrm{l})$ was fermented for one week under an aerobic conditions before application as a soail drench and $500 \mathrm{ml}$ of EM suspension solution were added to a bag.

3. A commercial complete chemical fertilizer 20N: 20P: $20 \mathrm{~K}+$ microelements) known as Ectaful was added also as a soil application at the rates of 2.5, 5.0, 7.5 and $10.0 \mathrm{~g} / \mathrm{bag}$. The chemical composition of such fertilizer is shown in Table (2).

4. EM solution at $25 \mathrm{ml} / \mathrm{l}$ was combined with each level of NPK commercial fertilizer to form 4 combinations as follows:

a. EM at $25 \mathrm{ml} / 1+\mathrm{NPK}$ fertilizer at $2.5 \mathrm{~g} / \mathrm{bag}$.

b. EM at $25 \mathrm{ml} / 1+\mathrm{NPK}$ fertilizer at $5.0 \mathrm{~g} / \mathrm{bag}$.

c. EM at $25 \mathrm{ml} / \mathrm{l}+\mathrm{NPK}$ fertilizer at $7.5 \mathrm{~g} / \mathrm{bag}$.

d. EM at $25 \mathrm{ml} / \mathrm{l}+\mathrm{NPK}$ fertilizer at $10.0 \mathrm{~g} /$ bag.
Data were then tabulated, and the morphological ones were subjected to analysis of variance according to SAS Institute Program (1994) was used for statistical analysis, whereas Duncan's Multiple Range Test (1955) was employed to verify the differences among the means of different treatments.

\section{RESULTS AND DISCUSSION}

\subsection{Effect of fertilization treatments on 3.1.1. Vegetative growth parameters}

It is evident from Table (3) that all fertilization treatments employed in general improved, all vegetative growth parameters with various significant differences when compared to the untreated control in both seasons. It was also noticed that EM alone gave means closely near to those of NPK fertilizer at $5 \mathrm{~g} / \mathrm{bag}$, with few exceptions in the two seasons, while combining between these two treatments gave the utmost high means over the control and all

Table (2): The chemical composition of the commercial NPK fertilizer used in the two seasons.

\begin{tabular}{|l|c|l|l|l|c|}
\hline \multicolumn{1}{|c|}{ Component } & Value & Component & Value & Component & Value \\
\hline Nitrogen (N) & $20 \%$ & Chelated Fe & $700 \mathrm{ppm}$ & Chelated Zn & $140 \mathrm{ppm}$ \\
Phosphorus (P) & $20 \%$ & Chelated Mn & $420 \mathrm{ppm}$ & Chelated Mo & $140 \mathrm{ppm}$ \\
Potassium (K) & $20 \%$ & Chelated Cu & $160 \mathrm{ppm}$ & Boron (B) & $220 \mathrm{ppm}$ \\
\hline
\end{tabular}

The previous treatments were applied 4 times commencing from mid April till mid October (one every two months). The experimental treatments in both seasons were arranged in a complete randomized design (Mead et al., 1993) and the treatments were replicated 3 times with 3 offshoots for each replicate, i.e. 10 treatments X3 replicates X3 offshoots $=90$ offshoots for each season. All the offshoots received the usual agricultural practices recommended for such plantation whenever needed.

At the end of each season (the end of October), the following measurements were recorded: length of the first new formed leaf $(\mathrm{cm})$, number of the new formed leaves / offshoot, trunk length and circumference $(\mathrm{cm})$ and fresh and dry weights of the first new leaf $(\mathrm{g})$. In fresh leaf samples taken from the leaflets of the first new leaf, photosynthetic pigments (chlorophyll a, b and carotenoids, $\mathrm{mg} / \mathrm{g}$ f.w.) and the total indoles were determined according to the methods of Moran (1982) and A.O.A.C. (1980), respectively, while in dry leaf samples, the percentages of nitrogen (using micro-Kieldahle method described by Pregli, 1945) and potassium (using flame photometer set as explained by Jackson, 1973) were evaluated. other individual or combined treatments in both seasons. Increasing the rate of NPK fertilizer to $7.5 \mathrm{~g} / \mathrm{bag}$ or more did not induce valuable additional increment in the growth, whereas combining between EM treatment and NPK fertilizer at any level did so, especially between $25 \mathrm{ml} / \mathrm{l} \mathrm{EM}$ and $5 \mathrm{~g} \mathrm{NPK} / \mathrm{bag}$ combination, which was superior over all other sole and combined treatments in both seasons, as mentioned before.

Thus, using NPK complete fertilizer with EM biostimulant seemed to be valuable for enhancing growth through providing the plants with macro-and micro-nutrients necessary for good and healthy growth, inducing plant disease resistance by EM, which also creates humus substances and regulates basic relations in the soil (Janas, 2009). Moreover, EM may play a role in enhancing the enzymatic systems in the plant tissues, and consequently activating growth (Thach et al., 1999).

Means within columns having the same letters are not significantly difficent according to Duncan mulitiple rang test (1955)

The present results are in harmony with those postulated by Abdel-Galeil (2010a and b) on date palm cvs. Malacabe and Sakkoty, 
Table (3): Effect of fertilization treatments on some vegetative growth traits of Phoenix dactylifera $l$. cv . Siwi during 2014 and 2015 seasons.

\begin{tabular}{|c|c|c|c|c|c|c|}
\hline Treatments & $\begin{array}{l}\text { Length of } \\
\text { the first } \\
\text { new leaf } \\
\text { (cm) }\end{array}$ & \begin{tabular}{|c|}
$\begin{array}{c}\text { No. the } \\
\text { new } \\
\text { leaves/ off } \\
\text { shoot }\end{array}$ \\
\end{tabular} & $\begin{array}{c}\text { Trunk } \\
\text { length } \\
\text { (cm) }\end{array}$ & $\begin{array}{c}\text { Trunk } \\
\text { circumference } \\
\text { at the base } \\
(\mathrm{cm})\end{array}$ & $\begin{array}{l}\text { F.W. the } \\
\text { first new } \\
\text { leaf } \\
(\mathrm{g})\end{array}$ & $\begin{array}{l}\text { D.W. the } \\
\text { first new } \\
\text { leaf } \\
(\mathrm{g})\end{array}$ \\
\hline & \multicolumn{6}{|c|}{ First seasons 2014} \\
\hline Control & $63.00 \mathrm{e}$ & $2.00 \mathrm{c}$ & $28.67 \mathrm{f}$ & $25.37 \mathrm{f}$ & $64.31 \mathrm{~d}$ & $30.50 \mathrm{c}$ \\
\hline $\mathrm{EM}$ at $25 \mathrm{ml} / \mathrm{l}(\mathrm{A})$ & $75.40 \mathrm{~cd}$ & $3.00 \mathrm{~b}$ & $36.00 \mathrm{~d}$ & $31.33 \mathrm{e}$ & $68.40 \mathrm{c}$ & $33.16 \mathrm{bc}$ \\
\hline NPK at $2.5 \mathrm{~g} / \mathrm{bag}(\mathrm{B})$ & $72.33 \mathrm{~d}$ & $3.00 \mathrm{~b}$ & $31.50 \mathrm{e}$ & $30.50 \mathrm{e}$ & $66.35 \mathrm{~cd}$ & $32.18 \mathrm{cb}$ \\
\hline NPK at $5.0 \mathrm{~g} / \mathrm{bag}(\mathrm{C})$ & $75.65 \mathrm{~cd}$ & $3.33 \mathrm{~b}$ & $38.46 \mathrm{~cd}$ & $31.60 \mathrm{e}$ & $68.50 \mathrm{c}$ & $33.44 \mathrm{bc}$ \\
\hline NPK at $7.5 \mathrm{~g} / \mathrm{bag}(\mathrm{D})$ & $78.00 \mathrm{c}$ & $3.33 \mathrm{~b}$ & $45.00 \mathrm{bc}$ & $39.73 \mathrm{c}$ & $73.33 \mathrm{~b}$ & $35.20 \mathrm{~b}$ \\
\hline NPK at $10.0 \mathrm{~g} / \mathrm{bag}(\mathrm{E})$ & $78.33 \mathrm{c}$ & $3.00 \mathrm{~b}$ & $46.10 \mathrm{~b}$ & $37.00 \mathrm{~d}$ & $72.38 \mathrm{~b}$ & $35.00 \mathrm{~b}$ \\
\hline$A+B$ & $76.10 \mathrm{~cd}$ & $3.33 \mathrm{~b}$ & $45.33 \mathrm{~b}$ & $44.00 \mathrm{~b}$ & $70.45 \mathrm{bc}$ & $34.56 \mathrm{bc}$ \\
\hline$A+C$ & $113.33 \mathrm{a}$ & $4.00 \mathrm{a}$ & $53.67 \mathrm{a}$ & $51.00 \mathrm{a}$ & $80.34 \mathrm{a}$ & $41.78 \mathrm{a}$ \\
\hline$A+D$ & $92.48 \mathrm{~b}$ & $3.33 \mathrm{~b}$ & $38.70 \mathrm{~cd}$ & $42.71 \mathrm{bc}$ & $77.50 \mathrm{ab}$ & $36.85 \mathrm{~b}$ \\
\hline \multirow[t]{2}{*}{$A+E$} & $93.21 \mathrm{~b}$ & $3.33 \mathrm{~b}$ & $41.33 \mathrm{c}$ & $39.80 \mathrm{c}$ & $73.44 \mathrm{~b}$ & $35.22 \mathrm{~b}$ \\
\hline & \multicolumn{6}{|c|}{ Second seasons 2015} \\
\hline Control & $56.33 \mathrm{~g}$ & $2.33 \mathrm{c}$ & $31.30 \mathrm{e}$ & $26.33 \mathrm{e}$ & $60.33 \mathrm{e}$ & $30.00 \mathrm{~d}$ \\
\hline $\mathrm{EM}$ at $25 \mathrm{ml} / 1(\mathrm{~A})$ & $68.10 \mathrm{e}$ & $3.00 \mathrm{bc}$ & $40.00 \mathrm{c}$ & $33.50 \mathrm{~d}$ & $68.14 \mathrm{de}$ & $31.34 \mathrm{~cd}$ \\
\hline NPK at $2.5 \mathrm{~g} / \mathrm{bag}(\mathrm{B})$ & $61.79 \mathrm{f}$ & $3.00 \mathrm{bc}$ & $35.67 \mathrm{~d}$ & $31.67 \mathrm{~d}$ & $67.13 \mathrm{ed}$ & $33.18 \mathrm{c}$ \\
\hline NPK at $5.0 \mathrm{~g} / \mathrm{bag}(\mathrm{C})$ & $71.50 \mathrm{ed}$ & $3.33 \mathrm{~b}$ & $43.33 \mathrm{~b}$ & $42.33 \mathrm{~b}$ & $70.45 \mathrm{~d}$ & $35.23 \mathrm{bc}$ \\
\hline NPK at $7.5 \mathrm{~g} / \mathrm{bag}(\mathrm{D})$ & $74.00 \mathrm{~d}$ & $3.00 \mathrm{bc}$ & $37.90 \mathrm{dc}$ & $41.00 \mathrm{~b}$ & $73.40 \mathrm{c}$ & $36.20 \mathrm{~b}$ \\
\hline NPK at $10.0 \mathrm{~g} / \mathrm{bag}(\mathrm{E})$ & $72.43 \mathrm{de}$ & $3.00 \mathrm{bc}$ & $36.50 \mathrm{~d}$ & $37.38 \mathrm{c}$ & $72.12 \mathrm{~cd}$ & $35.03 \mathrm{bc}$ \\
\hline$A+B$ & $76.00 \mathrm{~cd}$ & $3.33 \mathrm{~b}$ & $41.86 \mathrm{bc}$ & $36.51 \mathrm{c}$ & $75.33 \mathrm{cb}$ & $35.11 \mathrm{bc}$ \\
\hline$A+C$ & $95.97 \mathrm{a}$ & $4.33 \mathrm{a}$ & $50.98 \mathrm{a}$ & $53.00 \mathrm{a}$ & $85.48 \mathrm{a}$ & $42.16 \mathrm{a}$ \\
\hline$A+D$ & $88.33 \mathrm{~b}$ & $3.00 \mathrm{bc}$ & $40.36 \mathrm{c}$ & $41.83 \mathrm{~b}$ & $78.43 \mathrm{~b}$ & $37.10 \mathrm{~b}$ \\
\hline$A+E$ & $79.00 \mathrm{c}$ & $3.00 \mathrm{bc}$ & $38.39 \mathrm{~cd}$ & $40.33 \mathrm{~b}$ & $73.12 \mathrm{c}$ & $35.14 \mathrm{bc}$ \\
\hline
\end{tabular}

Means within colams having be letters are not significantly difficent according to Duncan mulitiple rang test

Kandeel et al. (2002) on Melia azedarach, Agina et al. (2005) on Ficus macrocarpa cv. Hawaii, Abdel-Fattah et al. (2009) on Dracaena and Ruscus and El-Sayed (2012) who elicited that complete fertilizer $(19: 19: 19+$ micronutrients) at $2 \mathrm{~g} /$ pot plus EM at $1 \mathrm{ml} / 1$ as a soil drench gave the best growth, density and color in seashore paspalum turf.

\subsubsection{Leaf chemical composition}

The data averaged in Table (4) show that the percentages of $\mathrm{N}, \mathrm{P}$ and $\mathrm{K}$ were markedly increased in the leaves of the plants treated with either NPK complete fertilizer or EM biostimulant, alone or in combination over the percentages gained by the untreated plants in the two seasons. The least records of these nutrients in both seasons were found due to EM solution $(25 \mathrm{ml} / \mathrm{l})$ and the low rates of NPK fertilizer when each of them was applied alone. However, conbining between EM and the complete fertilizer gave higher records, especially when the combining between EM at $25 \mathrm{ml} / \mathrm{l}$ and NPK fertilizer at $5 \mathrm{~g} / \mathrm{bag}$, as this combination registered the highest content at all in both seasons. A similar response occurred as well in respect of the total indole content (ppm) and pigments content (mg/g F.W.) in the two seasons, except for EM solution and NPK fertilizer at $10.0 \mathrm{~g} / \mathrm{bag}$ treatments which gave less content of chlorophyll $\mathrm{b}$ in the first season than the control $(0.055$ and $0.058 \mathrm{mg} / \mathrm{g}$ f .w., respectively against $0.064 \mathrm{mg} / \mathrm{g} \quad$ F.W. for control), and EM solution alone that recorded less content of carotenoids than control in the two seasons $(0.058 \mathrm{mg} / \mathrm{g} \mathrm{f}$.w. against 0.070 $\mathrm{mg} / \mathrm{g}$ f.w. for control in the $1^{\text {st }}$ season, and 0.061 $\mathrm{mg} / \mathrm{g}$ f.w. against $0.072 \mathrm{mg} / \mathrm{g}$ f.w. for the control in the $2^{\text {nd }}$ one).

In general, the prevalence in all previous constituents' content was for the combined treatment of $25 \mathrm{ml} / \mathrm{l} \mathrm{EM}+5 \mathrm{~g} / \mathrm{bag}$ NPK complete fertilizer which scored the utmost high records in both seasons.

These findings are reasonable because the presence of EM, as a biostimulant reinforce the beneficial effects of NPK fertilizer which supply the plants with the different nutrients necessary for good growth, besides the role of 
Table (4): Effect of fertilization treatments on the chemical composition of Phoenix dactylifera L.cv. Siwi leaves during 2014 and 2015 seasons.

\begin{tabular}{|c|c|c|c|c|c|c|c|}
\hline \multirow[t]{2}{*}{ Treatments } & \multirow[t]{2}{*}{$\mathbf{N} \%$} & \multirow[t]{2}{*}{$\mathbf{P} \%$} & \multirow[t]{2}{*}{ K \% } & \multirow{2}{*}{$\begin{array}{l}\text { Total indoles } \\
\text { (ppm) }\end{array}$} & \multicolumn{3}{|c|}{ Pigments content (mg/ g f.w.) } \\
\hline & & & & & Chlo.a & Chlo.b & Carotenoids \\
\hline & \multicolumn{7}{|c|}{ First seasons 2014} \\
\hline Control & 1.78 & 0.11 & 1.07 & 0.139 & 0.099 & 0.064 & 0.070 \\
\hline EM at $25 \mathrm{ml} / 1(\mathrm{~A})$ & 2.47 & 0.15 & 1.19 & 0.226 & 0.182 & 0.055 & 0.058 \\
\hline NPK at $2.5 \mathrm{~g} / \mathrm{bag}(\mathrm{B})$ & 2.33 & 0.16 & 1.26 & 0.198 & 0.120 & 0.068 & 0.073 \\
\hline NPK at $5.0 \mathrm{~g} / \mathrm{bag}(\mathrm{C})$ & 2.56 & 0.28 & 1.50 & 0.377 & 0.156 & 0.068 & 0.097 \\
\hline NPK at $7.5 \mathrm{~g} / \mathrm{bag}(\mathrm{D})$ & 2.90 & 0.30 & 1.50 & 0.240 & 0.133 & 0.079 & 0.099 \\
\hline NPK at $10.0 \mathrm{~g} / \mathrm{bag}(\mathrm{E})$ & 2.71 & 0.26 & 1.63 & 0.293 & 0.137 & 0.058 & 0.096 \\
\hline$A+B$ & 2.50 & 0.31 & 1.44 & 0.232 & 0.376 & 0.087 & 0.100 \\
\hline$A+C$ & 3.31 & 0.43 & 1.72 & 0.521 & 1.182 & 0.183 & 0.127 \\
\hline$A+D$ & 2.95 & 0.30 & 1.58 & 0.395 & 0.490 & 0.076 & 0.093 \\
\hline \multirow[t]{2}{*}{$A+E$} & 2.95 & 0.24 & 1.50 & 0.253 & 0.286 & 0.065 & 0.089 \\
\hline & \multicolumn{7}{|c|}{ Second seasons 2015} \\
\hline Control & 1.81 & 0.10 & 1.13 & 0.143 & 0.095 & 0.062 & 0.072 \\
\hline $\mathrm{EM}$ at $25 \mathrm{ml} / 1(\mathrm{~A})$ & 2.50 & 0.13 & 1.20 & 0.231 & 0.174 & 0.074 & 0.061 \\
\hline NPK at $2.5 \mathrm{~g} / \mathrm{bag}(\mathrm{B})$ & 2.37 & 0.15 & 1.27 & 0.198 & 0.124 & 0.064 & 0.077 \\
\hline NPK at $5.0 \mathrm{~g} / \mathrm{bag}(\mathrm{C})$ & 2.61 & 0.21 & 1.45 & 0.373 & 0.231 & 0.071 & 0.090 \\
\hline NPK at $7.5 \mathrm{~g} / \mathrm{bag}(\mathrm{D})$ & 2.95 & 0.27 & 1.51 & 0.393 & 0.190 & 0.076 & 0.091 \\
\hline NPK at $10.0 \mathrm{~g} / \mathrm{bag}(\mathrm{E})$ & 2.70 & 0.30 & 1.60 & 0.370 & 0.135 & 0.084 & 0.086 \\
\hline$A+B$ & 2.63 & 0.30 & 1.50 & 0.391 & 0.277 & 0.090 & 0.091 \\
\hline$A+C$ & 3.18 & 0.36 & 1.76 & 0.458 & 1.310 & 0.181 & 0.115 \\
\hline$A+D$ & 2.87 & 0.28 & 1.63 & 0.239 & 0.383 & 0.103 & 0.101 \\
\hline$A+E$ & 2.90 & 0.25 & 1.51 & 0.352 & 0.381 & 0.092 & 0.094 \\
\hline
\end{tabular}

EM in increasing the surface unit area of root length and hence enhancing the root hair branching with an eventual increase in acquisition of nutrients from the soil solution (Primavesi,1999). These positive responses were also acknowledged by numerous investigators such as Abdel-Galeil et al. (2010) on date palm cv. Zaghloul, Gad (2003) on Ficus benjamina, El-Sayed et al. (2008) on Ficus macrocarpa cv. Hawaii and Shahin et al. (2014) on Merremia dissecta. In this regard, El-Seginy (2006) declared that the use of organic fertilizer $(10: 10$ : 10+ micro-nutrients and humates) and EM biostimulant on young Le Conte pear and Canino apricot trees grown in calcareous soil gave vigorous growth and increased leaf nutrients content. It also decreased the cost production and boosted the income.

From the aforementioned results, it can be advised to treat the 2-year-old offshoots of date palm cv. Siwi with EM solution $(25 \mathrm{ml} / \mathrm{l})$ plus NPK complete fertilizer $(5 \mathrm{~g} / \mathrm{bag})$ to improve their vegetative growth and quality.

\section{REFERENCES}

Abdel-Fattah G. H., El-Sayed B. A. and Khenizy S. A. M. (2009). Response of Dracaena and Ruscus plants to humic acid and biofertilizer supply. Ann. Agric. Sci., Moshtohor, 47(1): 111-119.

Abdel-Galeil L. M. (2010a). Response of date palm plantlets $\mathrm{cv}$. Malacabe to some fertilization treatments. J. Biol. Chem. \& Environ. Sci., 5(1): 43-55.

Abdel-Galeil L. M. (2010b). Improving the growth of date palm cv. Sakkoty, plantlets by some fertilization treatments. J. Biol. Chem. \& Environ. Sci., 5(1): 109-122.

Abdel-Galeil L. M., El-Sayed B. A. and Shahin S. M. (2010). Response of date palm cv. Zaghloul off shoots to phloroglucinol and humic acid under nursery conditions. J. Biol. Chem. \& Environ. Sci., 5(4): 39-52.

Agina Eman A. M., Shalaby H. S., El-Khayat A. S. and Korkor H. M. (2005). Effect of foliar fertilization and some growth regulators on growth and chemical composition of some ornamental plants. Proc $6^{\text {th }}$ Arab Conf. Hort., 20-22 March, Dept. Hort., Fac. Agric., Ismailia, Egypt, Abst.: 10.

A.O.A.C. (1980). Official Methods of Analysis 
of the Association Official Agricultural Chemists. $15^{\text {th }}$ Ed., Arlington, Virginia USA. 22201:877-878.

Duncan D. B. (1955). Multiple range and multiple F-tests. J. Biometrics, 11:1-42

El-Fouly A. S., Abdel-Moniem A. M. and Ibrahim H. E. (2014). Response of the slow-growing Mistletoe Fig (Ficus deltoidea Jack) plant to fertilization treatments and growth activator. II. Humic acid liquid fertilizer treatment. Scientific J. Flowers \& Ornam. Plants, 1(1): 25-34.

El-Sayed B. A. (2012). Response of seashore paspalun to treatment with kristalon and biostimulant EM. Minufiya J. Agric. Res., 37(4): 935-941.

El-Sayed B. A., El-Fouly A. S. and El-Feky A. H. (2008). Response of Ficus macrocarpa L. var. Hawaii transplants to some fertilization treatments. Egypt. J. Appl. Sci., 23(1): 224-231.

El-Seginy A. M. (2006). Effect of the organic fertilizer (Actosol) and EM biostimulant on vegetative growth and chemical composition of young pear and apricot trees grown in calcareous soil. J. Agric. Sci., Mansoura Univ., 31(5): 3147-3158.

Gad M. M. (2003). Evaluation of various potting media and fertilizer levels for commercial nursery production of Ficus benjamina L. Assuit J. Agric. Sci., Fac. Agric., Assuit Univ., Egypt, 34: 123151.

Jackson M. (1973). Soil chemical analysis. Prentice - Hall of India private Ltd. M97,New Delhi, India, 498pp.

Janas R. (2009). Posibilities of using effective microorganisms in organic production systems of cultivated crops. Proplemy Inzynierri Rolniczei, 17(3): 111-119.

Kandeel Y. M., El-Tarawy M. A. and ElMahrouk E. M. (2002). Response of Melia azedarach L. to fertilization and irrigation treatments in Nuberia. $2^{\text {nd }}$ Inter. Conf. Hort Sci., 10-12 Sept., Kafr El-Sheikh, Tanta Univ., Egypt: 484-499.

Mead R., Curnow R. N. and Harted A. M. (1993). Statistical methods in agriculture and experimental biology, $2^{\text {nd }}$ Ed., chapman \&hall ltd., london 335pp.
Moran R. (1982). Formula for determination of chloophyllous pigments extracted with N-N- dimethy 1 formamide. Plant physiol., 69:1376-81

Pregli F. (1945). Quantitative Organic MicroAnalysis, $4^{\text {th }}$ Ed., J. and A. Churchill Ltd., London, P.203-209.

Primavesi A. M. (1999). Determination of plant health by their magnetic emanation and its improvement with EM. $5^{\text {th }}$ Inter. Conf. on Kyusei nature Farming, Bangkok, Thailand, 23-26 Oct., 219225.

Richards L. A. (1954). Diagnosis and Improvement saline and Alkali Soils. USDA, Handbook No.60.

Sarhan A., Abou-Dahab T., Abdel-Dayem A. M. and Rabie A. R. (2002). NPK fertilization of Taxodium disticum seedlings. $2^{\text {nd }}$. Inter conf. Hort Sci., 1012 Sept. Kafr El-Sheikh, Tanta Univ., Egypt: 1342-1358.

Sarhan A., El-Maadawy E. I. and Surour S.S. (2007). Effect of biopromotors and biofertilizers application on growth and chemical composition of jojoba plants. J. Agric. Sci., Mansoura Univ., Egypt, 32(8): 6575-6598.

SAS Institute (1994). SAS/STAT User's Guides Statistics. Vers. 6.04, $4^{\text {th }}$ Ed., SAS Institute Inc., Cary, N.C., USA.

Shahin S.M., El-Tayeb H. F. and El-Sayed B. A. (2012). Effect of some media and fertilization treatments on growth and quality of some foliage pot-plants. J. Biol. Chem. \& Environ. Sci., 7(1): 93112.

Shahin S.M., El-Sayed B. A. and El-Tayeb H. F. (2014). Improving growth and quality of Merremia dissecta (Jacq.) H. G. Hallier twiner by some fertilization treatments. Alex. J. Agric. Sci., 59(1): 43-49.

Thach N. Q., Long C.A., Liet V., Trung N. V., Thanh N. X., Dichi T.V., Duong N., Tuan N. K., Xuan L.T.H. and Dar P.V. (1999). Preliminary results of EM application in Vietnam. $5^{\text {th }}$ Inter. Conf. on Kyusei Nature Farming, Bangkok, Thailand, 23-26 Oct. P.254-260. 


\section{استجابة فسائل نخيل البلح للمنشط الحيوي EM و التسميد الكيماوى تحت ظروف المشتل \\ لبنى محمد عبد الجليل \\ المعمل المركزي لأبحاث وتطوير نخيل البلح - مركز البحوث الزر اعية ـ الجيزة ـ مصر.}

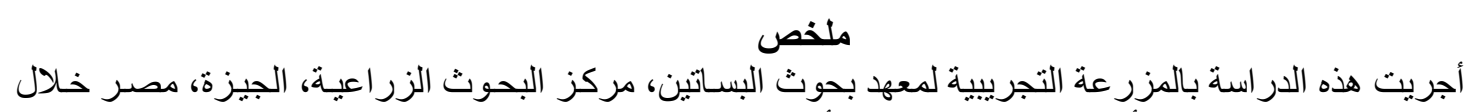

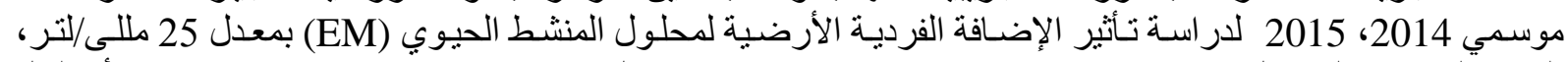

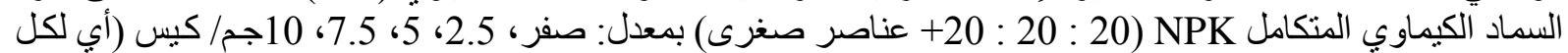

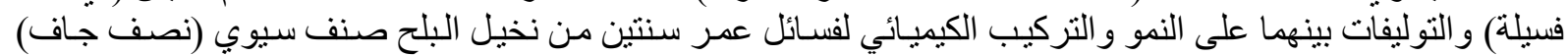

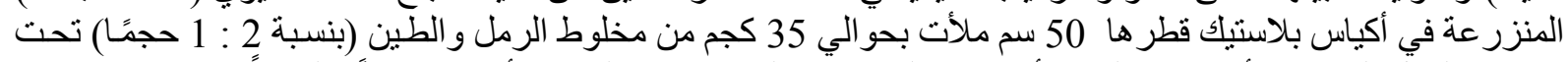

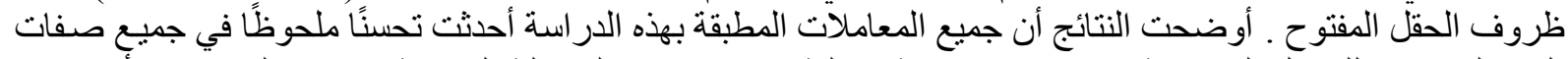

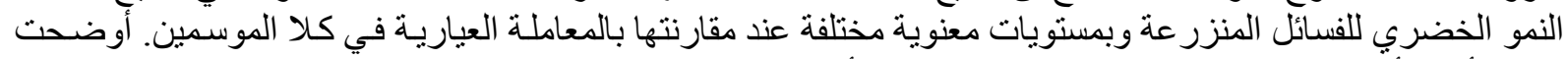

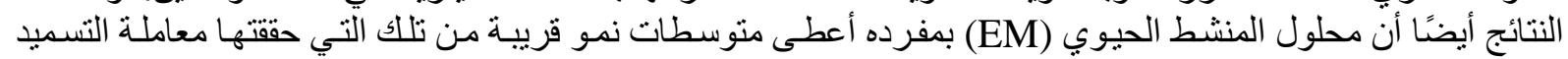

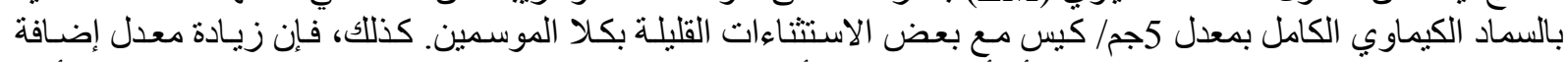

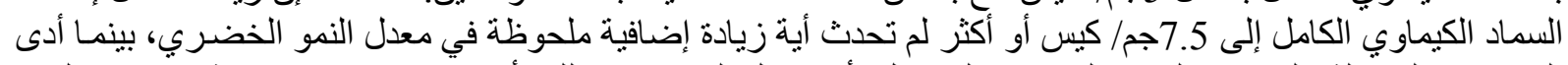

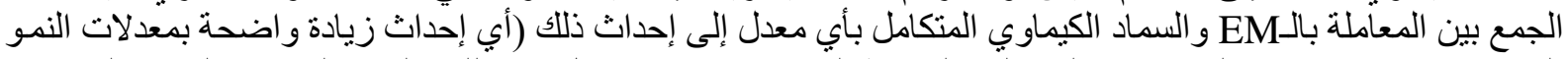

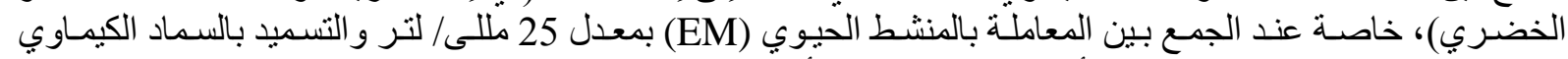

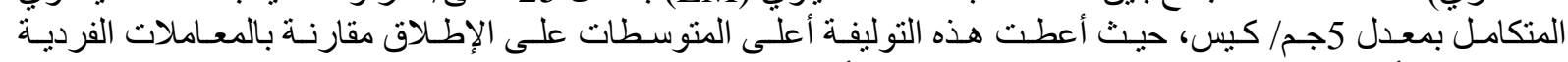

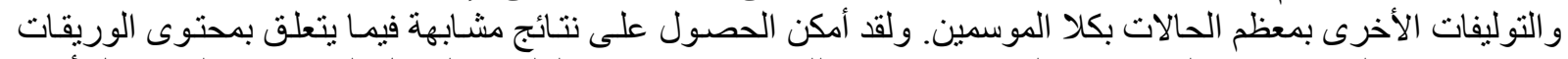

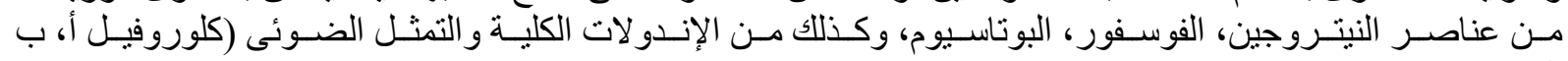

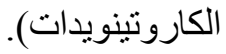

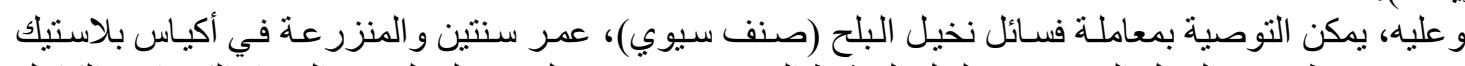

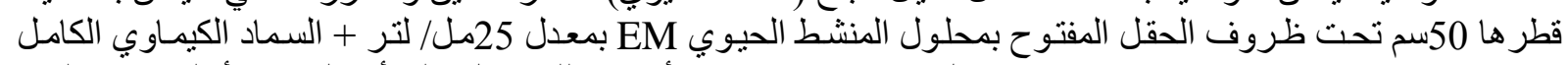

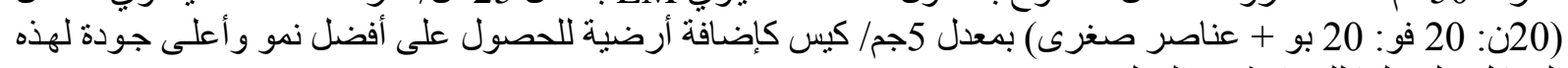
الفسائل قبل نقلها للزر اعة في الحقل. 